\title{
Synthesis and Structural Characterization of 6-(N-Methyl-pyridin-2-ylcarbamoyl)- pyridine-2-carboxylic Acid Methyl Ester Isomers
}

(Sintesis dan Pencirian Struktur Isomer 6-(N-Metil-piridina-2-ylkarbamoil)-piridina-2-karboksilik Asid Metil Ester)

\author{
MAISARA ABDUL KADIR*, NAFISAH MANSOR \& UWAISULQARNI M. OSMAN
}

\begin{abstract}
A series of monoamide isomers have been successfully synthesised and characterised using combination of common spectroscopic techniques such Fourier Transform Infrared (FT-IR), ${ }^{1} \mathrm{H}$ and ${ }^{13} \mathrm{C}$ Nuclear Magnetic Resonance (NMR) and Ultraviolet-visible (UV-vis). The monoamide compounds namely 6-(3-methyl-pyridin-2-ylcarbamoyl)-pyridine2-carboxylic acid methyl ester (L1), 6-(4-methyl-pyridin-2-ylcarbamoyl)-pyridine-2-carboxylic acid methyl ester (L2), 6-(5-methyl-pyridin-2-ylcarbamoyl)-pyridine-2-carboxylic acid methyl ester (L3) and 6-(6-methyl-pyridin-2ylcarbamoyl)-pyridine-2-carboxylic acid methyl ester (L4) were prepared from reaction between 6-(methoxycarbonyl) pyridine-2-carboxylic acid with 2-amino- $N$-methylpyridine (where $N=3,4,5$ and 6) by using acyl chloride reaction. In this present studies, the synthesis and characterization of these compounds are discussed along with the inductive effects contributed by methyl substituted groups at the pyridine ring.
\end{abstract}

Keywords: Acyl chloride; inductive; isomers; monoamide; pyridine

\section{ABSTRAK}

Suatu siri isomer baru monoamida telah berjaya disintesis dan dicirikan menggunakan gabungan beberapa teknik spektroskopi seperti Fourier Penukar Inframerah (FTIR), ${ }^{1} \mathrm{H}$ dan ${ }^{13}$ C Resonans Magnet Nukleus (RMN) dan Ultra-lembayung boleh nampak (UV-vis). Sebatian yang dinamakan sebagai 6-(3-metil-piridin-2-ilkarbamoil)-piridina-2-karboksilik asid metil ester (L1), 6-(4-metil-piridin-2-ilkarbamoil)-piridina-2-karboksilik asid metil ester (L2), 6-(5-metil-piridin-2ilkarbamoil)-piridina-2-karboksilik asid metil ester (L3) dan 6-(6-metil-piridin-2-ilkarbamoil)-piridina-2-karboksilik asid metil ester (L4) dihasilkan daripada tindak balas antara 6-(metoksikarbonil)piridin-2-karboksilik asid dengan 2-amino- $N$-metilpiridin (dengan $N=3,4,5$ dan 6) menggunakan kaedah asil klorida. Dalam kajian ini, kaedah sintesis dan pencirian struktur sebatian berikut akan dibincangkan bersama kesan induktif yang disumbangkan oleh kumpulan penukarganti metil pada gegelang piridin.

Kata kunci: Asil klorida; induktif; isomer; monoamida; piridina

\section{INTRODUCTION}

The development in the synthesis of new amide compounds has progressed rapidly due to their increasing demand in several applications such as bioconjugates, bioactive macrocylic drugs, nanostructures and organic linker in supramolecular architectures (Ardona \& Tovar 2015; Dunetz et al. 2016; Leggio et al. 2015; Lenstra et al. 2015; Pattabiraman \& Bode 2011; Zivec et al.2009). Among of many reported amides, little attention has been paid on the synthesis of amides containing pyridine (aminopyridyl in particular), even though their application as organic linker in the construction of coordination polymers has nowadays become a great attention. According to Zhang (2009), the study was limited by the synthesis and purification of aminopyridyl's procedure that are tedious and problematic. This is because, aminopyridyl molecules has labile functionalities that requires activation for substitution reaction to be occurred (Devi et al. 2015; Janeta et al. 2014; Zhang et al. 2009). To overcome this problem, an acyl chloride was used as precursor to activate the amine sites and promote nucleophilic substitution reaction. Although the acyl chloride method is tedious; the interest in using acyl chloride reaction is still relevant for aminopyridyl preparation as this method is low-cost, environmental friendly and produce high yield of products (Zaragoza 2015). Therefore, we have used acyl chloride reactions to produce several aminopyridyl compounds which derived from pyridine dicarboxylic acid (AbdulKadir et al. 2011; Kadir et al. 2014). By using similar approach, again via this study, we have prepared a series of new isomers aminopyridyl compounds with substituted methyl group at the pyridine pendant arms. This study will discuss the preparation and chemistry of $6-(N$-methylpyridin-2-ylcarbamoyl)-pyridine-2-carboxylic acid methyl ester isomers along with their spectroscopic data.

According to literature, the substituted methyl at pyridine is described as $\alpha, \beta$ and $\gamma$, not ortho, meta and para as in other aromatic rings (Figure 1). Meanwhile, 
<smiles>[CH2]C1CCCNC1</smiles>

$\alpha$<smiles>Cc1ccncc1</smiles>

$\beta$<smiles>Cc1cccnc1</smiles><smiles>Cc1cccc(C)n1</smiles>

FIGURE 1. Description of methyl substituted position at pyridine ring

structure 4 is described as $(2,6)$ with regards to the position of methyl at that respective positions (Boon et al. 1986). The structure of four new compounds prepared in this study is shown in Figure 2.

\section{MATERIALS AND METHODS}

All chemicals or reagents used were purchased from standard supplier (Merck and Sigma Aldrich) and used as received without further purification. The infrared (IR) spectra were recorded on a Fourier Transform-Infrared Spectrometer, Perkin Elmer Spectrum 100 in the range of $4000-400 \mathrm{~cm}^{-1}$ using potassium bromide (KBr) pellets. For UV-Vis analysis, all compounds were recorded by using Spectrophotometer Shimadzu UV-1601PC in $1 \mathrm{~cm}^{3}$ cuvette in methanolic solution for absorbance analysis. NMR spectra of ${ }^{1} \mathrm{H}$ and ${ }^{13} \mathrm{C}$ NMR were recorded using Bruker Advance III 400 spectrometer with deuterated chloroform $\left(\mathrm{CDCl}_{3}\right)$ the solvents and chemical shift values were given in parts per million ( $\mathrm{ppm}$ ) relative to solvent resonances as internal standard. Melting points were measured using Melting Point Stuart SMP3 while CHNS elemental analyses were recorded by CHNS Flashes 1112 series.

\section{SYNTHESES OF MONOAMIDE COMPOUNDS}

A suspension of 6-(methoxycarbonyl)pyridine-2carboxylic acid $(0.5 \mathrm{~g}, 2.0 \mathrm{~mol})$ was heated at reflux in dichloromethane in the presence of thionyl chloride $(0.5$ $\mathrm{mL})$ and a little amount of dried DMF $(1 \mu \mathrm{L})$ as catalyst under nitrogen. After an hour, the dichloromethane was removed using rotary evaporator and leave in vacuum desiccator for another one hour to remove all the solvent. The acyl chloride $(1.67 \mathrm{~g}, 3.5 \mathrm{~mol})$ was redissolved in dichloromethane (40 mL), before 2-amino-3-methyl pyridine $(1.567 \mathrm{~g}, 3.5 \mathrm{~mol})$ and distilled triethylamine (1.7 mL, $3.5 \mathrm{~mol})$ were added. The mixture was heated at reflux for another $24 \mathrm{~h}$. After the reaction was completed, the solvent was removed using rotary evaporator. Then the residue was redissolved with dichloromethane, washed with sodium hydrogen bicarbonate to remove unreacted starting material. Dichloromethane was dried over magnesium sulfate and the solvent removed using rotary evaporator under reduced pressure. The resulting residue was purified by column chromatography on silica gel eluting with 8:2 ethyl acetate: dichloromethane. The product was obtained as powder from column as pale yellow precipitate. The rest of the compounds (L2-L4) were prepared using similar methods described for L1, by replacing 2 -amino-3-methyl pyridine with 2 -amino4-methyl pyridine, 2-amino-5-methyl pyridine and 2-amino-6-methyl pyridine, respectively. All compounds were obtained in moderate to good yields, approximately $70-88 \%$.

\section{RESULTS AND DISCUSSION}

Compounds 6-(3-methyl-pyridin-2-ylcarbamoyl)pyridine-2-carboxylic acid methyl ester (L1), 6-(4-methylpyridin-2-ylcarbamoyl)-pyridine-2-carboxylic acid methyl ester (L2), 6-(5-methyl-pyridin-2-ylcarbamoyl)-pyridine2-carboxylic acid methyl ester (L3) and 6-(6-methylpyridin-2-ylcarbamoyl)-pyridine-2-carboxylic acid methyl ester (L4) were prepared from acyl chloride reactions, which involve continuous steps of combination between 6-(methoxycarbonyl)pyridine-2-carboxylic acid (6-mpcd), thionyl chloride and aminopyridine in inert condition (Scheme 1). In the synthesis of the compound, acyl chloride was prepared as precursor before being reacted with amine. In the reaction, the activated amine from aminopyridyl will attack the acyl carbonyl and forming the isomers (Scheme 2).

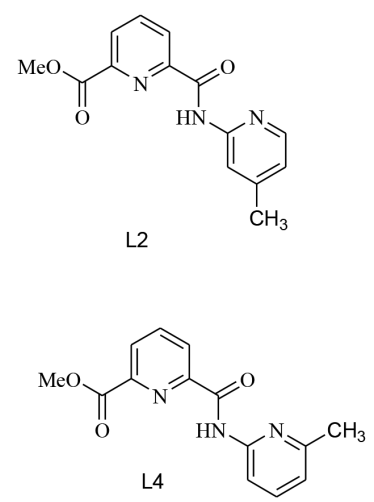




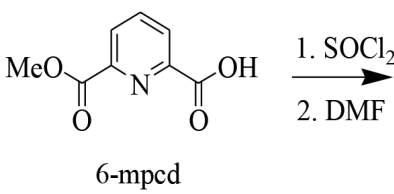

$\mathrm{CH}_{3}=\mathrm{a}(\mathrm{L} 1), \mathrm{b}(\mathrm{L} 2), \mathrm{c}(\mathrm{L} 3), \mathrm{d}(\mathrm{L} 4)$

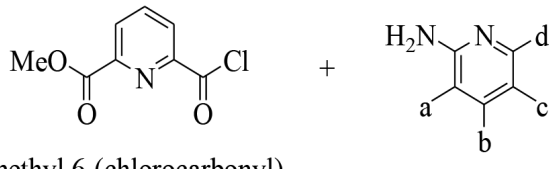

methyl 6-(chlorocarbonyl) picolinate<smiles>COC(=O)c1cccc(C(=O)Nc2nc(Cl)c(C)c(Br)c2Br)n1</smiles>

L1-L4

SCHEME 1. General synthetic reaction for the synthesis of L1-L4<smiles>CCOCC(=O)c1cccc(C(=O)OC)n1</smiles><smiles>Cc1cccnc1N</smiles><smiles>C=CC</smiles>

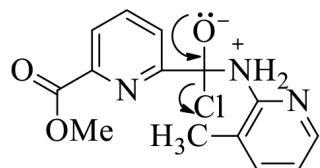<smiles>COC(=O)c1cccc(C(=O)Nc2ncccc2C)n1</smiles>

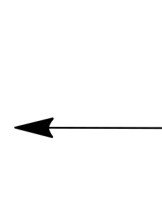<smiles>COC(=O)c1cccc(C(=O)NCc2cccnc2CCCl)n1</smiles>

SCHEME 2. Proposed mechanism for the formation of L1

In the FTIR spectra of L1-L4, several distinctive peaks for $\mathrm{N}-\mathrm{H}$ stretching, $\mathrm{N}-\mathrm{H}$ bending and $\mathrm{C}=\mathrm{O}$ stretching were indicated at range 3339-3358, 1525-1535 and 1699-1742 $\mathrm{cm}^{-1}$, respectively (Figure 3 ). From the IR spectra, it was observed that compound L4 has the highest frequency of $\mathrm{NH}$ stretching found at $3358 \mathrm{~cm}^{-1}$. This might be due to the position of methyl substituted that is far from amino (NH) and experienced less steric effect compared to L1-L3. The shift might also attribute by intramolecular hydrogen bonding that shifts the $\mathrm{N}-\mathrm{H}$ stretching to higher frequency as reported by Sharma et al. (2011). In contrast to N-H stretching, the peaks for methyl group shows insignificant different and were found at range 2920-2962 and 1320$1324 \mathrm{~cm}^{-1}$, respectively. It is obvious from this study that the methyl groups for these four compounds were indicated at lower frequency which is below than $3000 \mathrm{~cm}^{-1}$ due to the behaviour of $\mathrm{CH}_{3}$ that formed $\mathrm{sp}^{3}$ hybridization (Lanigan et al.2013). The $\mathrm{CH}$ bending for mono substituted phenyl ring was also observed at the range $682-685 \mathrm{~cm}^{-1}$, in similar to the spectroscopic data reported by Yalcin et al. (2015). As shown in Figure 2, compounds L1-L4 are differed in methyl position at the pyridine pendant arms. Methyl, which is an electron donating group (EDG), pulls the electron density away from the hydrogen towards carbon. This resulted to inductive effects which led to the increment of electron density at carbon atoms. This explains why the compound with methyl at $\gamma$ position experienced more electron donating effects compared to $\beta$, therefore 


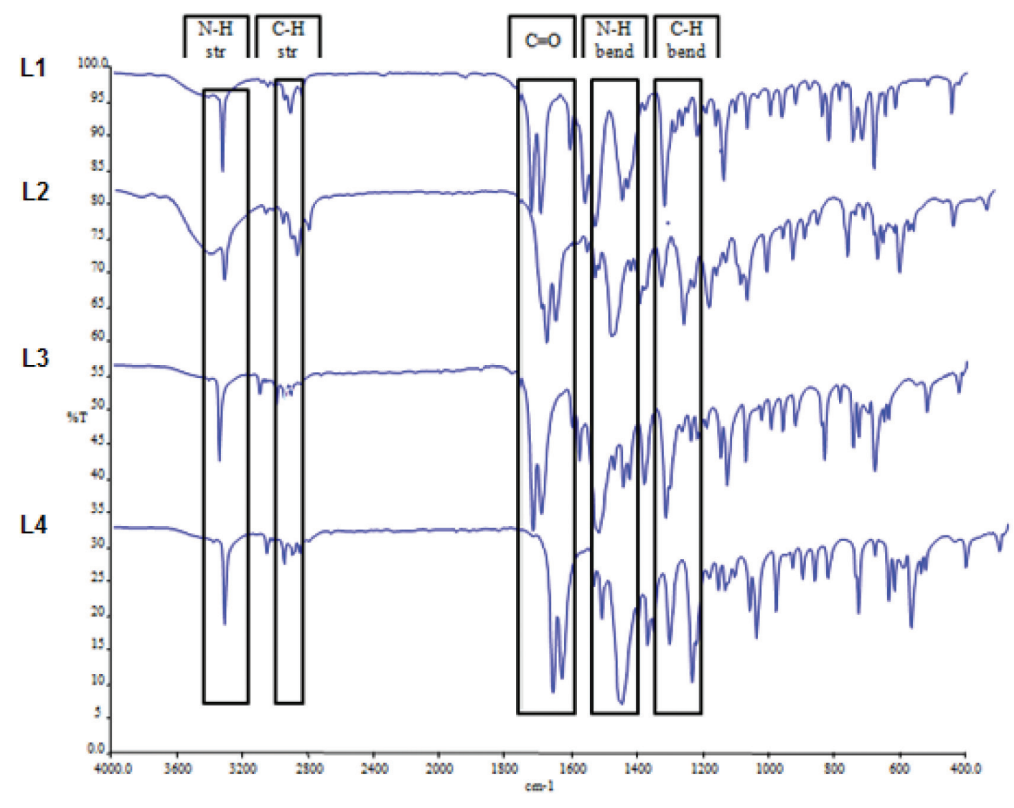

FIGURE 3. The FTIR spectra for L1, L2, L3 and L4

the frequency of $\mathrm{C}=\mathrm{O}$ and $\mathrm{N}-\mathrm{H}$ at $\gamma$ position was found at higher region compared to the compound with methyl at $\alpha$ and $\beta$ positions. This was also related to the shortening of the bond lengths between methyl, $\mathrm{C}=\mathrm{O}$ and $\mathrm{N}-\mathrm{H}$ due to this inductive phenomenon (Diaz-Alejo et al. 2013). The comparison between the functional groups obtained from the IR spectra is shown in Tables 1 and 2 .

In the ${ }^{1} \mathrm{H}$ NMR spectra for L1-L4, the resonances for two methyl group $\left(\mathrm{CH}_{3}\right)$ are indicated at range 2.36-2.53 ppm and 4.0-4.06 ppm, respectively. According to the data showed in Table 3, the resonance for $\mathrm{C}-\mathrm{H}$ methyl that attached to pyridyl appeared further downfield (2.53 ppm) compared to the other isomers, due to the position of the methyl substituted that is near to the nitrogen atom of the pyridine. Compound L3, which has methyl substituted at $\gamma$ position that has a less steric effect towards amino shows $\mathrm{NH}$ resonance at further downfield (10.41 ppm). In the ${ }^{13} \mathrm{C}$ NMR spectrum, the resonances of two $\delta\left(\mathrm{CH}_{3}\right)$ were observed at $17.93-53.05 \mathrm{ppm}$. The resonance signals for pyridine, $\delta$ (C-aromatic pyridine) were indicated at 111.13-157.28 ppm while $(\mathrm{C}=\mathrm{O})$ peaks were found further downfield around 161.27-164.99 ppm. The methyl that attached to oxygen atoms shifts to the downfield region due to the electronegativity of the oxygen (Jakob et al. 2015; Lanigan et al. 2013; Wilson et al. 2012). In this case, the pyridine ring protons are deshielded by the diamagnetic anisotropy of the ring and give the benzene ring protons a large chemical shift to 6.96-8.48 ppm (Park et al. 2013; Yalcin et al. 2015). The ${ }^{1} \mathrm{H}$ NMR and ${ }^{13} \mathrm{C}$ NMR spectra for L1 are shown in Figures 4 and 5, respectively.

The UV-Vis spectrum shows that compounds L1-L4 displayed two absorption peaks which corresponded to carbonyl $(\mathrm{C}=\mathrm{O})$ and pyridine (Figure 6$)$. The absorbance at $\lambda_{\max }$ 273-293 nm represents overlapping of $\mathrm{C}=\mathrm{O}$ group and pyridine group. The $\lambda_{\max }$ for L1 and L2 is lower than L3 and L4 and shift to longer wavelength. This is caused by molecule modification which is called as bathochromic effect. In this experiment, the molar absorptivity for $\mathrm{C}=\mathrm{O}$ and pyridine groups were determined as $2.73 \times 10^{7}-$ $2.93 \times 10^{7} \mathrm{~L} \mathrm{~mol}^{-1} \mathrm{~cm}^{-1}$ which led to $\mathrm{n} \rightarrow \pi^{*}$ transition and $\pi \rightarrow \pi^{*}$ transition, respectively. Yalcin et al. (2015) had stated that, amide and benzoyl carbonyl group had $\mathrm{n} \rightarrow \pi^{*}$ transition and phenyl ring had $\pi \rightarrow \pi^{*}$ transition. The data obtained is summarized in Table 3.

TABLE 1. Data comparison of IR spectra for L1-L4

\begin{tabular}{ccccc}
\hline $\begin{array}{c}\text { Vibrational } \\
\text { modes }\end{array}$ & $\mathrm{L} 1\left(\mathrm{~cm}^{-1}\right)$ & $\mathrm{L} 2\left(\mathrm{~cm}^{-1}\right)$ & $\mathrm{L} 3\left(\mathrm{~cm}^{-1}\right)$ & $\mathrm{L} 4\left(\mathrm{~cm}^{-1}\right)$ \\
\hline$v\left(\mathrm{CH}_{3}\right)$ & 2925 & 2923 & 2962 & 2920 \\
$v(\mathrm{~N}-\mathrm{H}$ str $)$ & 3339 & 3357 & 3350 & 3358 \\
$v(\mathrm{C}=\mathrm{O})$ & 1732,1702 & 1742,1727 & 1731,1702 & 1725,1699 \\
$v(\mathrm{~N}-\mathrm{H}$ bend $)$ & 1567,1535 & 1533 & 1533 & 1525 \\
$v\left(\mathrm{CH}_{3}\right.$ bend $)$ & 1324 & 1321 & 1322 & 1320 \\
\hline
\end{tabular}


TABLE 2. The selected data for the functional group (N-H and C-H) in the FTIR and NMR spectra of L1-L4

\begin{tabular}{|c|c|c|c|c|c|}
\hline \multirow{2}{*}{ Compounds } & \multicolumn{2}{|c|}{${ }^{1} \mathrm{H}$ NMR } & \multicolumn{2}{|c|}{ FTIR } & \multirow{2}{*}{ Structure } \\
\hline & $\delta(\mathrm{N}-\mathrm{H})$ & $\delta(\mathrm{C}-\mathrm{H})$ & $v(\mathrm{~N}-\mathrm{H}) \mathrm{str}$ & $v(\mathrm{~N}-\mathrm{H})$ bend & \\
\hline L1 & 10.28 & 2.39 & 3339 & 1535 & \\
\hline L2 & 10.28 & 2.45 & 3357 & 1533 & \\
\hline L3 & 10.41 & 2.36 & 3350 & 1533 & \\
\hline L4 & 10.36 & 2.53 & 3358 & 1520 & \\
\hline & & & & & $\mathrm{C}_{9} \mathrm{H}_{6} \mathrm{NO}_{3}$ \\
\hline
\end{tabular}

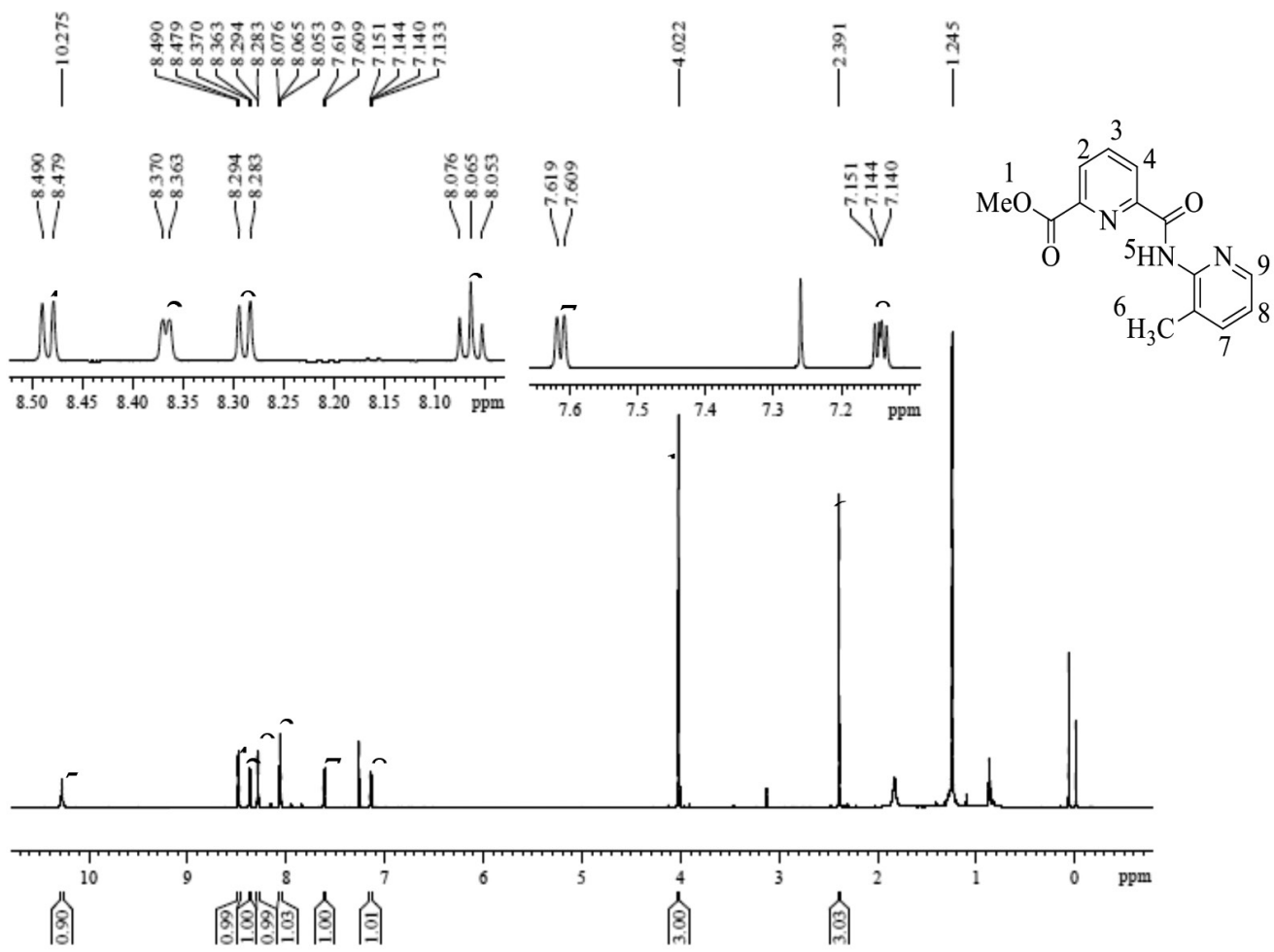

FIGURE 4. ${ }^{1} \mathrm{H}$ NMR spectrum of monoamide ligand, L1

Several approaches have been attempted to crystallise these compounds, however no crystals were obtained. This might due to the high polarity of the compounds that prohibits them to crystallise in any solvents, where the product precipitate after each of crystallization was attempted. However, the combination of spectroscopic studies particularly NMR has proved that the studied molecules are successfully obtained as expected. 


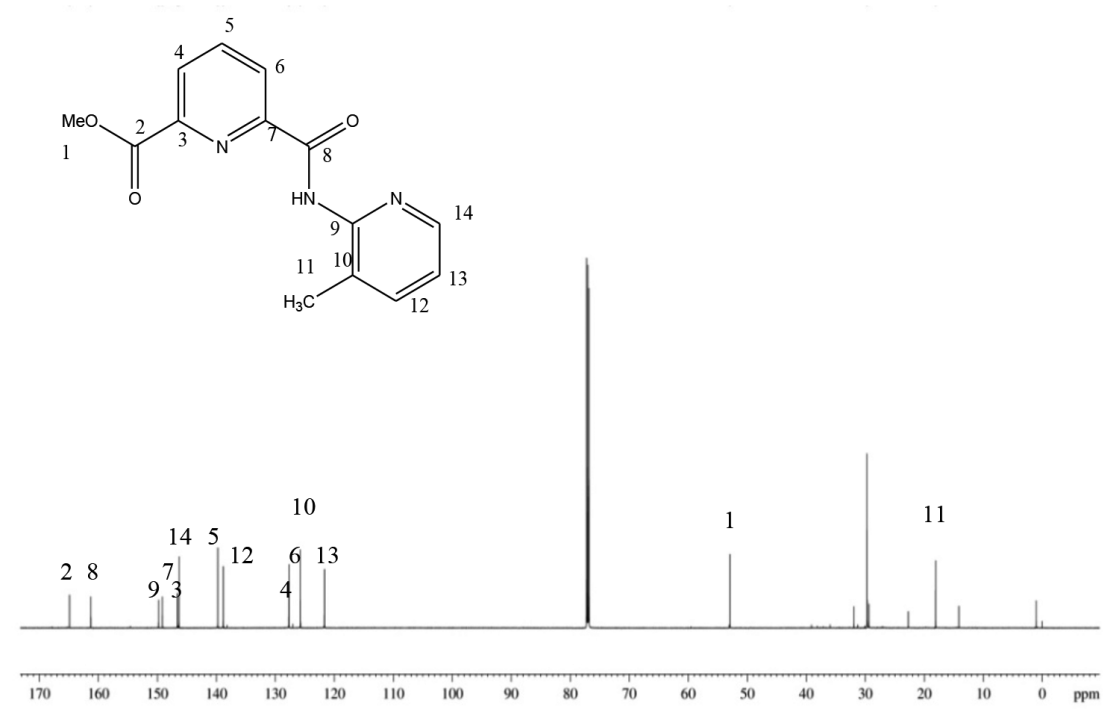

FIGURE $5 .{ }^{13} \mathrm{C}$ NMR spectrum of monoamide ligand, L1

TABLE 3. The UV-Vis data for L1-L4

\begin{tabular}{lllll}
\hline & Chromophores & Transition & $\lambda_{\max }(\mathrm{nm})$ & $\varepsilon, \mathrm{L} \mathrm{mol}^{-1} \mathrm{~cm}^{-1}$ \\
\hline L1 & Pyridine, C=O & $\mathrm{n} \rightarrow \pi^{*}, \pi \rightarrow \pi^{*}$ & 273 & $2.73 \times 10^{7}$ \\
L2 & Pyridine, C=O & $\mathrm{n} \rightarrow \pi^{*}, \pi \rightarrow \pi^{*}$ & 273 & $2.73 \times 10^{7}$ \\
L3 & Pyridine, C=O & $\mathrm{n} \rightarrow \pi^{*}, \pi \rightarrow \pi^{*}$ & 293 & $2.93 \times 10^{7}$ \\
L4 & Pyridine, C=O & $\mathrm{n} \rightarrow \pi^{*}, \pi \rightarrow \pi^{*}$ & 291 & $2.91 \times 10^{7}$ \\
\hline
\end{tabular}

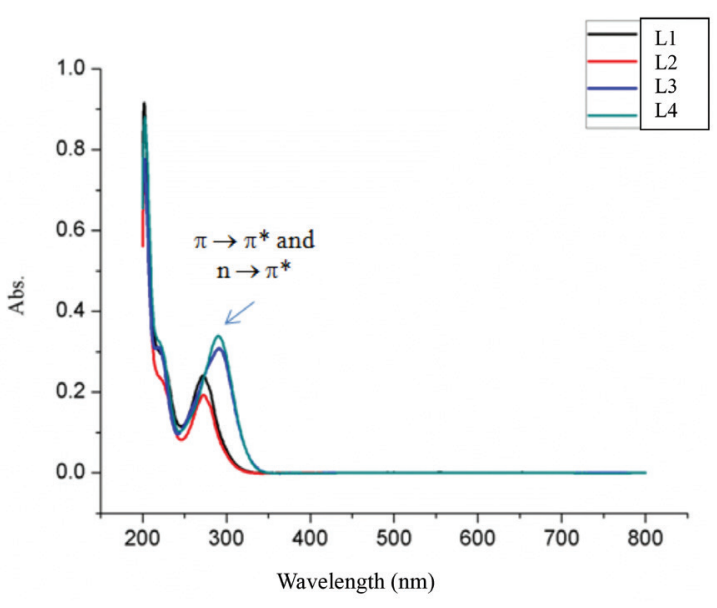

FIGURE 6. UV-Vis spectra for L1-L4

\section{CONCLUSION}

In conclusion, a series of monoamide compounds namely 6-(3-methyl-pyridin-2-ylcarbamoyl)-pyridine-2carboxylic acid methyl ester (L1), 6-(4-methyl-pyridin2-ylcarbamoyl)-pyridine-2-carboxylic acid methyl ester (L2), 6-(5-methyl-pyridin-2-ylcarbamoyl)-pyridine2-carboxylic acid methyl ester (L3) and 6-(6-methylpyridin-2-ylcarbamoyl)-pyridine-2-carboxylic acid methyl ester (L4) have been successfully synthesized by using acyl chloride methods. The different position of methyl substituents position has significant impacts towards the spectroscopic data, due to several factors such as inductive and steric effects. Compound L4 which has methyl nearby the nitrogen pyridine shows the highest frequency of $\mathrm{N}-\mathrm{H}$ stretching. Meanwhile, compound L3 and L4 that experienced less steric effects compared to the other isomers displays $\mathrm{N}-\mathrm{H}$ resonance at further downfield.

\section{ACKNOWLEDGEMENTS}

The authors greatly acknowledge the scientific support from Universiti Malaysia Terengganu. Ministry of Higher Education Malaysia is also acknowledged for the financial support through Fundamental Research Grant Projects (FRGS) Vot 59293.

\section{REFERENCES}

Abdul-Kadir, M., Sumby, C.J. \& Hanton, L.R. 2011. Selfassembled metallo-macrocycle based coordination polymers with unsymmetrical amide ligands. Dalton Trans 40: 1237412380 .

Ardona, H.A.M. \& Tovar, J.D. 2015. Peptide $\pi$-electron conjugates: Organic electronics for biology. Bioconjugate Chem. 26(12): 2290-2302.

Boon, J.A., Levisky, J.A., Pflug, J.L. \& Wilkes, J.S. 1986. FriedelCrafts reactions in ambient-temperature molten salts. Journal of Organic Chemistry 51: 480-483.

Devi, P., Barry, S.M., Houlihan, K.M., Murphy, M.J., Turner, P., Jensen, P. \& Rutledge, P.J. 2015. Synthesis and structural characterisation of amides from picolinic acid and pyridine2,6-dicarboxylic acid. Scientific Reports 5: 9950. 
Diaz-Alejo, L.A., Menchaca-Campos, E.C., Chavarin, J.U., Sosa-Fonseca, R. \& Garcia-Sanchez, M.A. 2013. Effects of the addition of Ortho- and Para- $\mathrm{NH}_{2}$ substituted tetraphenylporphyrins on the structure of nylon 66. International Journal of Polymer Science 2013: 14.

Dunetz, J.R., Magano, J. \& Weisenburger, G.A. 2016. Large-scale applications of amide coupling reagents for the synthesis of pharmaceuticals. Org. Process Res. Dev. 20(2): 140-177.

Jakob, U., Petersen, T.O. \& Bannwarth, W. 2015. Unusual metal complexes of $N, N$-bis(2-picolyl)amides - A comparative study of structure and reactivity. Journal of Organometallic Chemistry 797: 46-51.

Janeta, M., John, L., Ejfler, J. \& Szafert, S. 2014. High-yield synthesis of amido-functionalized polyoctahedral oligomeric silsesquioxanes by using acyl chlorides. Chem. Eur. J. 20: 15966-15974.

Kadir, M.A., Nafisah, M., Yusof, M.S.M. \& Sumby, C.J. 2014. Synthesis and crystal structure of $N-6$-[(4pyridylamino) carbonyl]-pyridine-2-carboxylic acid methyl ester zinc complex. Complex Metals 1: 32-37.

Lanigan, R.M., Starkov, P. \& Sheppard, T.D. 2013. Direct synthesis of amides from carboxylic acids and amines using $\mathrm{B}\left(\mathrm{OCH}_{2} \mathrm{CF}_{3}\right)_{3}$. J. Org. Chem. 78: 4512-4523.

Leggio, A., Belsito, E.L., Gioia, L.D., Leotta, V., Romio, E., Siciliano, C. \& Liguori, A. 2015. Silver acetate-assisted formation of amide from acyl chlorides. Tetrahedron Letters 56: 199-202.

Lenstra, D.C., Nguyen, D.T. \& Mecinovic, J. 2015. Zirconiumcatalysts direct amide bond formation between carboxylic esters and amines. Tetrahedron 71: 5547-5553.

Park,J.K.,Shin, W.K.\& An,D.K. 2013. New and efficient synthesis of amides from acid chlorides using diisobutyl(amino) aluminium. Bull. Korean Chem. Soc. 34: 1592-1594.

Pattabiraman, V.R. \& Bode, J.W. 2011. Rethinking amide bond synthesis. Nature 480: 471-479.

Sharma, A., Gupta, V., Mishra, R., Tandon, P., Maeda, S. \& Kunimoto, K.K. 2011. Study of vibrational spectra and molecular structure of intermolecular hydrogen bonded 2-thiohydantoin using density functional theory. Journal of Molecular Structure 1004: 237-247.
Wilson, S.O., Tran, N.T. \& Franz, A.K. 2012. NMR and X-ray studies of hydrogen bonding for amide-containing silanediols. Organometallics 31: 6715-6718.

Yalcin, S.P., Ceylan, U., Sarioglu, A.O. \& Sonmez, M. 2015. Sythesis, structural, spectral (FT-IR, ${ }^{1} \mathrm{H}$ and ${ }^{13} \mathrm{C}$ NMR and Uv-Vis), NBO and first order hyperpolarizability analysis of N-(4-nitrophenyl)-2, 2-dibenzoylacetamide by density functional theory. Journal of Molecular Structure 1098: 400-407.

Zaragoza, F. 2015. Amide compounds show a widely used in the many fields of sciences such as industrial, pharmacological and biological. J. Org. Chem. 80(20): 10370-10374.

Zhang, L., Wang, X.J., Wang, J., Grinberg, N., Krishnamurthy, D. \& Senanayake, C.H. 2009. An improved method of amide synthesis using acyl chlorides. Tetrahedron Letters 50: 2964-2966.

Zivec, M., Jakopin, Z. \& Gobec, S. 2009. Recent advances in the synthesis and applications of reduced amide pseudopeptides. Curr. Med. Chem. 16(18): 2289-304.

School of Fundamental Science

Universiti Malaysia Terengganu

21030 Kuala Terengganu, Terengganu Darul Iman Malaysia

*Corresponding author; email: maisara@umt.edu.my

Received: 20 July 2016

Accepted: 24 October 2016 